\title{
The Indigenization of Swedish and Hungarian Elements in Finnish Folk Dance
}

\author{
PETRI HOPPU \\ School of Social Sciences and Humanities, \\ University of Tampere
}

\begin{abstract}
This article discusses the influence of Hungarian folk dances and Swedish polskas on the Finnish folk dance movement. The central analytical tool in the study is Arjun Appadurai's concept of "indigenization": imported cultural elements take on local features and cultural hybrids develop. The Swedish polskas and Hungarian dances have created a new level of folk dancing in Finland, representing technical quality and skills that are commonly pursued. However, it is claimed that the indigenization of these dances entails that they have also been relocated and domesticated in Finland, and that they have become a part of the local embodied culture and discourse.
\end{abstract}

Key words: indigenization, folk dance, performance, dance event

In this article, I examine the development of the Finnish folk dance movement from the 1960s to the present. During the last few decades the movement has experienced several changes. Particularly, the unofficial, but still for many decades very influential national folk dance canon in Finland was challenged in many ways through the introduction of new folk dance forms, of which the Swedish polskas and Hungarian folk dances are the most significant and popular today. The process of "Swedenization" and "Hungarization" has continued for more than thirty years, and it has had a crucial impact on folk dance activities in Finland. Following Kevin Gotham's (2005: 312) ideas about cultural change, I claim that the development has by no means been linear; rather I see it as a complex and versatile process that has included both the homogenizing forces of sameness and uniformity and the diversifying forces of difference and hybridity. As I have been an active folk dancer and folk dance teacher since the early 1980s, I have been able to witness this development from a very close distance. A substantial part of the analysis is based on my own experiences, but I am also drawing on newspaper articles as well as a considerable amount of different material from the archive of 
the largest folk dance festival in the Nordic countries, Pispala Schottische in Tampere, Finland, as well as my own archive. ${ }^{1}$

The central analytical tool in my study is Arjun Appadurai's concept of "indigenization", which means that imported cultural elements take on local features and cultural hybrids develop. In brief, the unfamiliar and foreign is domesticated. According to Appadurai, cultural contacts and interaction seem to produce cultural homogenization, but in many cases the processes are closer to practices being taken on by local people and altered to fit their own environment. Indigenization helps us to understand how global-level developments affect local conditions and how these, for their part, reshape and convey global influences (Appadurai 1996: 29-32). It provides explanations to the changes in tradition, which is not just "handed down from the past" (Shils 1981: 12-21), but is socially constructed through embodied practices. The creation of tradition is a result of recontextualization, mixing of different identities and a fusion of symbols. Essentially, the production and sustenance of tradition is seen as taking place through interaction, in which people create meaning as well as produce shared understandings of their behaviour (Gotham 2005: 312).

\section{FOLK DANCE CANONS IN THE NORDIC COUNTRIES}

I am going to begin my examination by having a look at the roots of the revitalization of folk dances in Finland, beginning to take shape at the very end of the nineteenth century at the same time as in the other Nordic countries, excluding Iceland. The first organized folk dance group in the Nordic countries was the Swedish Philochoros, which was established by male students from the University of Uppsala in 1880. The group was successful not only in Sweden but also in the other Nordic countries where it toured, and its influence was remarkable in many respects: the group inspired people to establish new groups, its dances were commonly admired, and some of the emerging folk dance groups in the other Nordic countries, in addition to Swedish groups, adopted them. As a result, a certain common repertoire appeared in the Nordic countries, but what was even more important, national repertoires, which were later canonized, were constructed roughly following

\footnotetext{
${ }^{1}$ In addition to Hungary and Sweden, Russian Karelia, especially through the activities of the late ballet master Viola Malmi, was also significant. Viola Malmi and her dance groups visited Finland several times starting in the 1980s, introducing new dances and, most importantly, a new style of performing folk dances. However, Russian Karelian dances were included in the Finnish folk dance canon together with the Finnish Karelian dances starting in the early 1900s, so that Finnish folk dancers usually regarded the Russian Karelian impact as an internal modification, whereas Hungarian dances and Swedish polskas had a "non-Finnish" label.
} 
Philochoros's example in relation to its aesthetics, which became a kind of a Nordic model in folk dance canons (Hoppu 2011: 29-30).

Although the aim of the revitalization was to bring old vernacular dances, or dances that were considered vernacular dances, back to common dance events, revitalized folk dances were typically most often seen on stage. This fact certainly affected the ways that folk dance canons were constructed, and one can specify several common features in Nordic canons. First, in the canonized dances there was usually a clear and distinctive structure, which was written down so that the dance could be repeated in a similar manner as accurately as possible. There was practically no place for improvisation in the dance. Second, the formations of set dances like the square or two opposite lines became the ideal for Nordic folk dances, although couple dances were the most popular traditional dances especially in Sweden and Norway in the late nineteenth century. Third, the structure of the dance usually had its counterpart in the structure of a melody: musical phrases and the parts of the dance overlapped. Usually music bars would appear among dance instructions, but even if they did not, the structure of the dance had a clear connection to music: the dance started and ended along with the accompanying music. Fourth, the movements, steps that were used were articulated explicitly in detail. All the dancers were supposed to do the steps in a similar manner strictly following the same rhythm. If there were differences between the movements of the dancers, these were accurately regulated. The gestures were supposed to be sophisticated and modest. Dances taken into the national folk dance canon were considered authentic representations of the dance culture of the specific nation, and thus, the canons were believed to depict the culture in a truthful way. Canon construction legitimated the dances, and conversely, dances, seen as authentic, legitimated the canon. Consequently, both documented, traditional dances and composed or modified dances could appear side by side in publications without any problems (Hoppu 2011: 37-43).

The canonization process was not only a process of accepting and adopting but also of discriminating. The documented dance material that was mostly collected in the villages in the late 1800s and early 1900s included a lot of dances or features that were not regarded as proper for one reason or another, particularly since the most important goal was to perform them on stage. Brynjulf Alver (1980: 7-8) pointed out the selective character of the revitalization of folklore, which implies that different phenomena in the folk tradition were not regarded as equal: some elements of folklore were seen as more valuable than others. According to Alver, one important aspect that was emphasized was the age of folklore, the principle being: the older the better. Still, aesthetic aspects were essential as well, and in some cases, they were valued more highly than age. Heikki Laitinen (1986: 41-42) states 
that in Finland the ideal of Finnish folk song was not found in Kalevala songs, which were still appreciated for their antiquity, but in younger lyrical songs which were closer to the musical tastes of the educated people in the nineteenth century. Similarly in folk dance, both age and aesthetic aspects were significant when the national canons were established, but the latter ones became more prominent and could easily push the former aside.

Canons were not constructed intentionally, but emerged through different practices. One important channel in this process was the publication of folk dances. The publications were not ethnographic descriptions; rather their target groups were folk dance teachers and instructors, which means that they always had practical rather than scientific purposes. In Denmark the first three compiled folk dance volumes Danske Folkedanse I - III were first published between 1901-1911 by Foreningen til Folkedansens Fremme. In Norway, the most prominent Norwegian folk dance authority, Klara Semb, published Norske Folkedansar II. Rettleiding um dansen in 1922. This volume represents the typical repertoire of Norwegian folk dance movement at the beginning of the twentieth century, with multiple composed song dances as well as different set dances. For decades, the most important Swedish folk dance book was Svenska Folkdanser och Sällskapsdanser, which came out in several editions starting with 1933, edited by the leading figure in Swedish folk dance at that time, Gustaf Karlson. In Finland Anni Collan and Asko Pulkkinen, who were among the leading authorities in the early Finnish folk dance movement, edited several smaller volumes in the first half of the twentieth century, and finally, they both published compiled volumes of their earlier publications: Suomalaisia kansantanhuja (1929) by Pulkkinen and Suomalainen Kisapirtti (1928) by Collan. Moreover, in Swedish Finland, which can be seen as a separate "folk dance nation", ${ }^{2}$ several volumes were published by the Brage Association at the beginning of the twentieth century, but the first compiled volume was 30 folkdanser (1931), edited by Yngvar Heikel, the leading figure of Finnish Swedish folk dance for many decades.

Many publications reached nearly biblical status, although they were not necessarily a result of careful investigation: they often repeated the oral tradition which had come up in folk dance organizations and which was often a mixture of facts and myths about the origin of dances and dance traditions. The publications reveal a process of inclusion and exclusion connected to them: their contents address what dances and formations were favoured, and, when compared to documented dances, also what was ignored (Hoppu 2011: 31-32).

${ }^{2}$ The first Finnish folk dance association, Suomalaisen kansantanssin ystävät, was originally bilingual with both Finnish- and Swedish-speaking members, but after a couple years, the Swedish-speaking folk dancers left the association and joined Föreninen Brage, which was originally a temperance association in Helsinki with filial associations in other cities. However, folk dance became one of its main activities, and it was the leading Swedish-speaking folk dance organization in Finland until 1931 when a national organization, Finlands svenska folkdansring was founded (Huuskonen 2001). 
Since the 1960s the canons began to be challenged in various ways in the Nordic countries. In Sweden and Norway, many folk dancers had noticed a long time before that the canonized repertoires were quite far from the vernacular dances that still existed in the rural areas. In these countries a few enthusiasts began to document these dances, most of which were couple dances, and from the 1960s and 70s they replaced the old canons at least to some extent. In Sweden the result was that the folk dance field split into two segments, one of which kept to the old canon whereas the other adopted the newly discovered couple dances, mostly polskas, as the basic material of their repertoire. These segments are in many ways different and separate even today (Okstad 2007; Nilsson 2007).

In Finland, however, similar documentation did not emerge, but the development took another route. After World War 2, Soviet and other Eastern European folk dance groups visited Finland frequently, and like all over the Western World, they enjoyed enormous success. Tours of single groups created new contacts with folk dancers outside of Finland and the Nordic countries, and the Finnish folk dance field was gradually integrated into a global folk dance community through international organizations like the International Council of Organizations of Folklore Festivals and Folk Arts (CIOFF) and the International Organization of Folk Art (IOV), with the most important Finnish folklore festivals being their members since the 1970s.

The example of Soviet and Eastern European groups was particularly eagerly followed, and tendencies to create more spectacular performances emerged. To reach this goal, some Finnish folk dancers wanted to develop their technique in a more challenging direction, and consequently, they began to search for new movement vocabularies. Some of them were influenced by ballet or ballroom dancing, and later especially by contemporary dance, but what is of greatest interest to me, by foreign folk dance forms. On the whole, there have been teachers from many different countries around the world teaching folk dances from their country or region, and it can be said that Finnish folk dance has been strongly influenced by global flows during the last few decades. Even if one cannot point to any single culture as the main source of innovations, there are two countries whose influence has been particularly strong and long lasting: Hungary and Sweden. Contacts with these two countries were established as a part of larger international folk dance coordination, so they cannot be seen as separate cases. The relations between them and Finnish folk dancers belong to a larger network of international folklore and youth activities.

\section{THE HUNGARIAN INFLUENCE}

In the 1950s and 60s, Finnish folk dancers' contacts with Soviet and Eastern European groups as well as folk dance teachers became more intense. The 
first ones to invite them were communist youth organizations, especially the Finnish Democratic Youth League (Suomen Demokraattinen Nuorisoliitto, $S D N L$ ), which had folk dance in its activities since the early 1950s to mid 1960s. For example, teachers from the Soviet Estonia were regular visitors among folk dance groups of the SDNL (Kurkela 1986: 138-176). However the Estonians never influenced the substance or style of Finnish folk dance in any significant manner, and out of all Eastern European nations it would be Hungarians who would have the strongest and longest impact on Finnish folk dance.

The contacts between Finnish and Hungarian folk dancers were by no means exceptional, but Finland and Hungary had numerous cultural connections for many decades due to the fact that Finnish and Hungarian languages are related, although very distantly. Linguistic relatedness does not mean that Finns and Hungarians would have any common historical or cultural roots, but it implied strong cultural exchange starting with the late 1800s. Due to a more liberal atmosphere in Hungary during the 1960s, contacts became more intense from this decade on: since 1970 Finland was for many years the only Western country that the Hungarians could visit without a tourist visa (Unkari, http). As a result of this, together with the emergence of global networks in folklore, Finnish and Hungarian folk dancers began to create multiple connections between each other.

It was especially folk dancers within the largest folk dance organization, the Finnish Youth League (Suomen Nuorison Liitto, SNL), that eagerly established contacts with Hungarians, and it was during the 1960s that the first Hungarian folk dance teachers visited Finland. For example, the cultural secretary of the Finnish Youth League and one of the most prominent figure in Finnish folk dance, Sirkka Viitanen recorded ten Hungarian folk dance instructions that were described to her by the Hungarian dance teacher, Ágoston Lányi: Kalocsai páros, Tárkanyi paros, Vegyes körtánc, Lassú és friss, Gyertyás tánc, Tardi tanc, Matyó leánytánc, Somogyi páros, Csárdás and Aprozó. Many of them were choreographed by Lányi or other Hungarian dance teachers (Hungarian folk dance instructions... p. a.). In 1968, a Hungarian folk dance researcher András Béres gave a lecture on Hungarian folk dance and the current folk dance movement at the culture festival Jyväskylän kesä in Central Finland (Description of the lecture... p. a.). Moreover, Hungarian folk dance groups also became regular guests at the largest folk dance festival in Finland, Pispalan Sottiisi in Tampere, organized by the SNL and the city of Tampere since 1970, as well as at other folklore festivals.

Still, folk dance connections between Finland and Hungary were only occasional in the 1960s and early 1970s. Visiting groups were the most visible sign of the contacts, and Ágoston Lányi also regularly visited Finland at that time. A few Hungarian dances were included in the folk dance programme of elementary schools (Peruskoulun kansantanssiohjelmistoa 
1975, Kansantanssialan yhteistoimikunta), but otherwise, Hungarian dances were seldom seen in the repertoire of Finnish folk dance groups. The most important reason for this was probably that the difference between the skills of the Hungarian and Finnish folk dance groups was remarkable at that time. Many of the Hungarian groups were professional or had professional dance teachers, whereas in Finland folk dance was still based on amateur activities and only a few leaders had any dance teacher education, although many of them were, for example, PE teachers.

The situation, however, changed starting with the late 1970s, when a few Finnish folk dance groups began to train more intensively and even used professional dance teachers and choreographers with ballet or modern dance backgrounds. For example in 1975, Sirkka Viitanen together with a former prima ballerina of the Finnish National Ballet, Doris Laine, and the dance critic Irma Vienola-Lindfors established the group Katrilli, whose goal was to become the first professional folk dance group in Finland (Katrilli - Historia, http). ${ }^{3}$ As the level of Finnish folk dance groups rose, Finnish folk dancers became more interested in inviting professional folk dance teachers from abroad. Hungary was not the only country where they came from, but it was the most important one, since some Hungarian dance teachers also settled in Finland, either temporarily or permanently. Hungarian teachers mostly taught couple dances, for example from the Mezőség (Transylvania) and Szatmár regions as well as men's dances like Verbunks and girls' circle dances. A popular dance was also the Üveges tánc (Bottle dance). Moreover, the teachers who stayed in Finland for a longer time or settled there permanently would create their own choreographies. At the same time, the Hungarian dance house (tánzház) movement was introduced in Finland, and there were attempts to organize a similar activity in Finland as well. This, however, did not succeed, and the dance houses disappeared by the 1980s (Rajalaakso 1989). ${ }^{4}$

The impact of Hungarian folk dance teachers was to become more stable. In 1984 Béla Gazdag taught Hungarian dances at the international folk dance course organized by the SNL in Orivesi, Southern Finland, and after two years he moved to Northern Finland in order to work with folk dance groups, especially Rimpparemmi, which later became the first professional folk dance group in Finland. The fact that Gazdag actually moved to Finland permanently was nothing peculiar at the time, because a lot of Hungarian music teachers had done the same earlier. Later Gazdag moved to Hollola (Southern Finland), where he worked with several high-level amateur groups for many years. In addition to Gazdag, the dance master

\footnotetext{
${ }^{3}$ Although Katrilli received state funding for two decades, it never became a professional ensemble. However, it provided an example for later professional folk dance activities in the 1990s and later.

${ }^{4}$ It must added that since 1998 dance houses are being reestablished in Finland (Milad 2002: 6), and, at least in some parts of the country, they have had some success (Nuorisoseurat - Tanssitaloohjaajakoulutus, http).
} 
and choreographer of the Hungarian Military Academy, Janós Mucsi has been visiting Finland since the mid-80s, and he taught Hungarian folk dances, for instance in the ISOT group in Jyväskylä, Central Finland (ISOT Kansantanssia 50 vuotta, http).

The Hungarian influence could be seen quite soon in many ways in the repertoires of the most skilful Finnish folk dance groups. As early as 1989 the Rimpparemmi danced the Hungarian csárdás as a part of its performance celebrating the fifteenth anniversary of the group. According to Sirpa Heikkinen, who wrote a review of the performance, Rimpparemmi's csárdás really looked like a Hungarian dance (Heikkinen 1989). In 1994 Rimpparemmi celebrated its twentieth anniversary and it arranged a series of performances, one of which I was able to attend in Rovaniemi. The program consisted of canonized Finnish folk dances, modern Finnish choreographies and Hungarian folk dances. The Hungarian influence was striking in two ways: Hungarian dances took half of the whole performance, and additionally, Hungarian traits could be seen in the Finnish dances as well. Typically, Hungarian elements were added to virtuosic parts of Karelian dances, which have similar features as Russian dances (Notes from the performance... p. a.).

Rimpparemmi was not the only group that combined Hungarian elements with Karelian dances. In the same year (i.e. in 1994) the leader of the ISOT group, Tauno Häkkinen, participated in a contest for the best folk dance choreography at Pispala Schottische with his choreography Siirtokarjalainen lähtee Uudeltamaalta (An Evacuated Karelian Leaves the Uusimaa Province), whose name referred to its hybrid character. The choreography consists of traits from different parts of Finland, beginning with the Southern and Western style of dancing and ending with the Eastern, Karelian style. Interestingly, Häkkinen also uses Hungarian elements as part of the men's Karelian style of virtuosic dance. He does not even try to disguise these elements, and one of the most spectacular parts at the end of the choreography openly refers to Hungarian verbunks and other men's dances (Video of the folk dance...).

Finnish folk dance groups also started to perform larger dance productions choreographed by Hungarian folk dance teachers. In 1992 the Pispala Schottische festival granted the groups of the Saarenkylä Youth Club (Lapland) the title of the Folk Dance Group of the Year 1992. The groups had several performances at the festival that summer, but the most spectacular one took place at the Tampere Theatre. The program dedicated to war veterans and choreographed by a Hungarian folk dance teacher consisted mostly of elements from Hungarian dances. The choreography was created by a Hungarian folk dance teacher Lászlo Fülöp, and it consisted of nine parts: SOTA (War), Vuoropuhelu (Dialogue), Carmena burana, Metronomi (Metronome), Mise/kirkkotanssi (Mise/Church Dance), Noita (Witch), Ritmus (Rhythm), Varjo (Shadow) and Mezöségi. The intention of the performance was to hon- 
our Finland's 75th anniversary of independence as well as Finnish World War II veterans; and, for example, in the first part men danced in war-time uniforms (Description of the program... P. S. a.). In 1998, Rimpparemmi performed Kuoliaaksi tanssitettu tyttö (A Girl Danced to Death) by Joszef Botos in Helsinki, the capital of Finland, and the performance was highly celebrated in the largest subscription newspaper in Finland and the Nordic countries, Helsingin Sanomat (Räsänen 1998).

In addition to the introduction of Hungarian dances and larger dance performances in Finland as well as Hungarian elements in Finnish folk dances, Hungarian folk dance has even generated a totally new form of expression in Finnish folk dance. In 1992, some of the male dancers of the ISOT group in Jyväskylä established a sub-group called Tanhujätkät (Folk Dance Lads), and this group began to use Hungarian elements as a part of their versatile parody performances (ISOT - Kansantanssia 50 vuotta, http). Since 2010, a similar group of three men from the group ISOT, Tanhurentut (Folk Dance Yobs) has continued these activities with similar performances. Movements from Hungarian men's dances belong to the basic elements of the performances, but they also include a myriad of influences from Finnish folk dance to break dance (Tanhurentut, http).

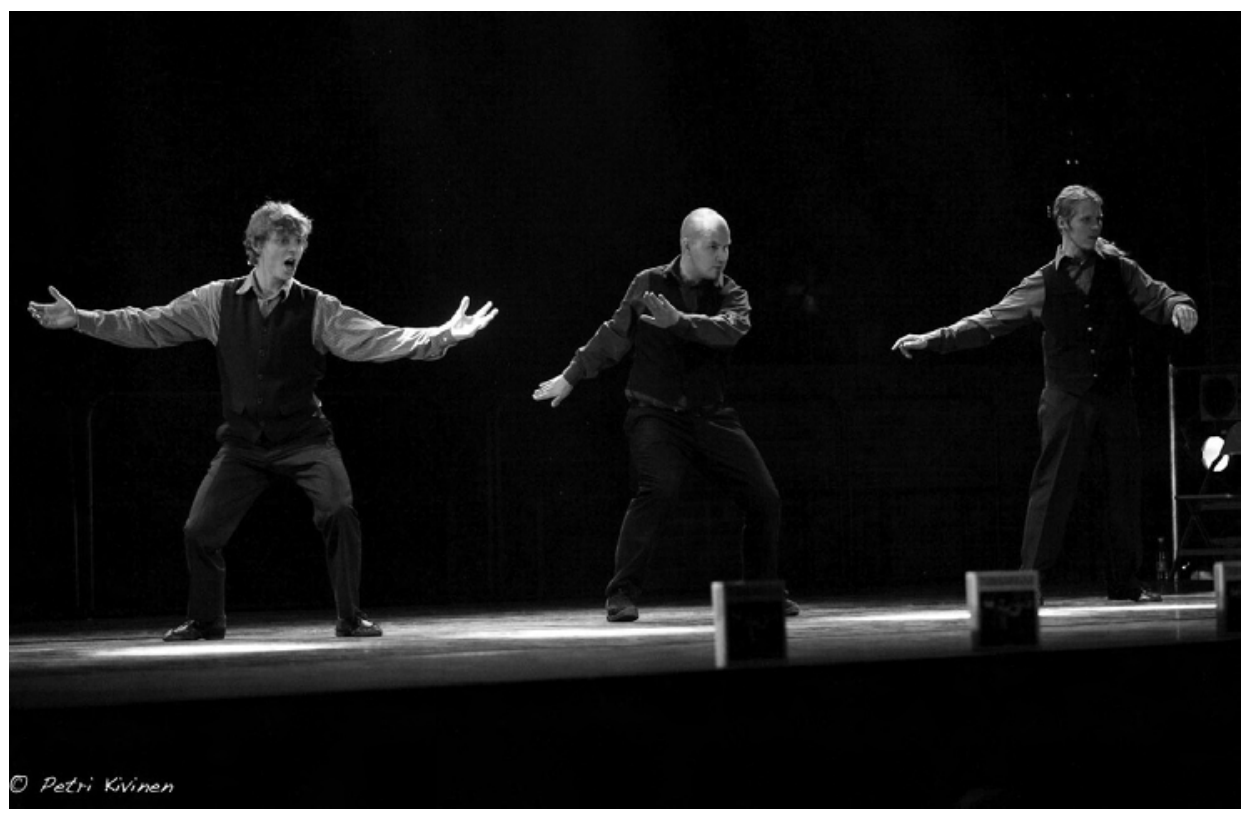

Figure 1: Tanhurentut (photo by Petri Kivinen) 


\section{THE SWEDISH POLSKA IN FINLAND}

In addition to various Hungarian dances, Swedish polskas entered the field of Finnish folk dance starting in the early 1980s. The polska is a dance that has been known in some forms in Finland as well, and in the early 1980s there were some attempts to revive it in Finland (Hoppu 2007). Thus, polska was not completely uncommon in Finland, although its Swedish forms represented a partly different movement vocabulary compared to Finnish folk dances.

In Sweden the polska is a walking and whirling couple dance in two forms: one is whirling and walking around the room and the other is rotating and walking in a single spot on the floor. The representatives of the second one are rather close to Finnish forms, and in Sweden they are often called slängpolskas but also simply polskas. The focus of these dances is on different holds and on the divisions between them. A typical slängpolska of this type could consist of two basic set positions: one in which the couple is spinning around one another while holding crossed hands outstretched with centrifugal force, the other in which the couple is spinning around one another in a closer position while holding the partner's shoulders and arms. Another type of the Swedish polska is sometimes also called slängpolska, but more commonly it is known as hambopolska, hamburska or polska. The basic structure of this type consists of couples moving counterclockwise around the room, and occasionally with a clockwise rotation of one turn for each 3/4 measure (Nilsson 2009: 74-81).

In 1981 one of the most prominent Swedish folk dance teachers Henry Sjöberg visited the international folk dance course in Orivesi and introduced some basic forms of Swedish släng- and hambopolskas (Henry Sjöberg's description..., p. a.). After that, several other Swedish dance teachers followed him during the first wave of Swedish polskas in the 1980s, and Swedish polskas were danced in many Finnish folk dance groups. However, mostly only the basic forms of släng- and hambopolskas were learnt in Finnish groups, and the more complicated ones were only seldom seen in Finland at that time.

One can specify two reasons for the increasing interest in Swedish polskas in Finland in the early 1980s. First, as already mentioned, the Swedish folk dance movement had experienced an almost a dramatic change during the 1960s and 1970s. The canonized repertoire had been challenged by new information, which was a result of active documentation of folk dances since the 1940s. The polskas became the core of the repertoire in the new Swedish folk dance movement, and due to intensive cooperation between folk dancers from Sweden and Finland, Finns became curious of what was going on in Sweden (see Hoppu 2014). Second, as also mentioned, there was a certain 
interest in the local polskas in Finland in the early 1980s (Hoppu 2007), and since Finnish and Swedish polskas have a common origin, it was considered natural to learn widely about this dance phenomenon.

However, after the early 1980s, the interest in Swedish polskas diminished for a while, although some occasional courses were given in the subsequent years. A clear exception was Rimpparemmi, whose contacts with Swedish, especially Northern Swedish and later also Norwegian folk dancers, increased rapidly during the 1980s and 90s, and the group regularly had Swedish polskas in its repertoire starting with the late 80s (Heikkinen 1989).

The second wave of polskas emerged in 1997, which was chosen as the year of the polska by the Kansanmusiikin Keskusliitto (The Central Union of Folk Music) in Finland. Once again Swedish folk dance teachers were invited to Finland in order to teach the multiple variations of different polska dances. This time, however, one could also see a change in direction as well: some Finnish polska enthusiasts travelled to Sweden to participate in polska courses there. This time the variety of the polska was even greater than before: they included complicated Western Swedish polskas from Dalarna and Värmland as well as Southern and Eastern Swedish slängpolskas in many forms.

Since the late 90s, the Swedish polska has influenced Finnish folk dance in many ways. The most skilful groups in particular included polska in their performances, although the original Swedish polska forms were seldom performed as such. Instead, folk dance choreographers would take elements from polskas and combined them with Finnish folk dance forms. Typically, Finnish folk dancers would not usually make any clear distinction between Swedish polskas and the hambo, both of which can be seen in folk dance performances and even in the same choreography, whereas in Sweden the former ones belong to the realm of folk dance and the latter ones to gammaldans (old time couple dances) (Urup, Sjöberg and Bakka 1984: 61-66).

However, Swedish polskas did not only influence folk dance performances, but most importantly, they entered the field of social dancing at different folk dance events. Social dancing has been an important part of the Nordic folk dance movement since the late 1800 s, and its significance has even increased during the last few decades. In Finland, the polska was seldom danced at these events before the end of the 1990s, but today it has become more and more popular especially among young dancers. Characteristically, dancers combine elements from different variations, and improvisation has become an important part of polska dancing. This is a phenomenon that can be seen in Sweden as well (Nilsson 2009: 34-39).

Today the polska has a special status among folk dancers in Finland. Finnish forms are still commonly danced, but they are not appreciated to any significant extent, because they are regarded as simple and also as some- 
what boring. However the various Swedish polska forms, hambopolskas, hamburskas, slängpolskas with dozens of different variations are considered extremely complicated, requiring careful practice under the instruction of skilled teachers. The Swedish polska has become the most appreciated form of couple dancing in Finland. This was manifested, for example, at an occasion where one of the best known Finnish folk dance teachers and choreographers, Antti Savilampi, received the Finnish state award for dance in 2010. To celebrate this, he chose to dance Swedish polskas with his partner, the dance artist and choreographer, Reetta-Kaisa Iles. This illustrates the exceptionally high status that the polska has in Finnish folk dance today.

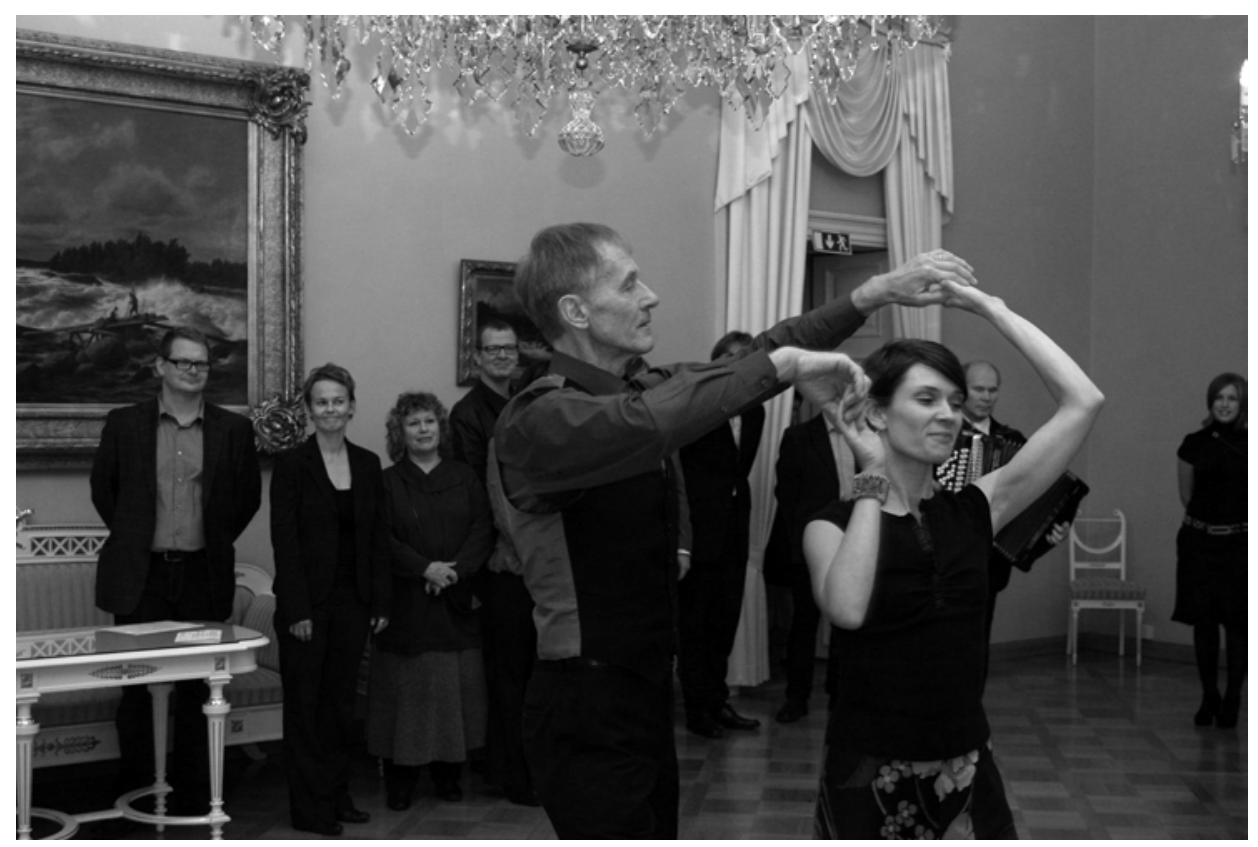

Figure 2: Antti Savilampi and Reetta-Kaisa Iles dancing the polska

(photo by Eija Ristimäki)

\section{“HUNGARIZATION” AND “SWEDENIZATION”}

One san see certain similarities between the Hungarian and Swedish influence in Finland, but there are remarkable differences as well. In both cases dances were introduced by teachers from the country of origin of the dance, who came to Finland to teach their dances. Moreover, both many of the Hungarian dances and Swedish polskas were regarded as technically chal- 
lenging, and they were first adopted by the most qualified groups and dancers. However, whereas Hungarian dances were almost completely used in dance performances, Swedish polskas have gradually become a part of folk dancers' social repertoire, their common dance events. Moreover, it should be emphasized that Swedish polskas have also attracted individual dancers and not only groups.

Still in both cases, the process has by no means been that of a simple adoption of foreign elements, but as I have shown, features of Hungarian, especially men's dances, and Swedish polskas have been fused into the Finnish folk dance repertoire in multiple ways. For many years Hungarian and Swedish dances were always performed as separate from Finnish folk dances, but this is not self-evident today. Actually nowadays, one can seldom see them performed in an "authentic" way, i.e. in a way they have been taught by the teachers from their country of origin. Instead, their elements are commonly merged with Finnish elements, either in stage choreography or in improvised social dancing. The Hungarian and Swedish influence has been further reinforced by the fact that both have been an important part of the vocational education of folk dance teachers and dancers. For example, Béla Gazdag has been teaching Hungarian dances at folk dance teacher education in Oulu as well as dancer education in Tampere and Rovaniemi for many years. This resulted in the fact that all professional folk dancers in Finland have been highly trained in both of them. Consequently, it is only natural that Hungarian and Swedish influence can be seen clearly in their work among Finnish folk dancers today.

What is apparent is the way in which foreign dance forms and movement vocabularies entered the Finnish folk dance field, connecting it to new "movementscapes". ${ }^{5}$ Swedish polskas and Hungarian dances travelled to Finland and they were indigenized by local folk dancers. According to Appadurai "at least as rapidly as forces from the various metropolises are brought into new societies, they tend to become indigenized in one way or another" (Appadurai 1996: 32). This is clearly what has happened in Finnish folk dance: dancers have taken new dance forms into their repertoire, learnt how to discuss and evaluate them, and constructed a new kind of expertise and creativity that is absent in the home countries of the forms.

The process of indigenization has implied both appreciation and appropriation. Although the origin of the dances is openly recognized, they are seen as a part of the dancers' embodiment and not as a manifestation of nationality. Nowadays, it is actually seldom that one refers to nationality in discourses related to them; rather, they are regarded as virtuosic dimen-

${ }^{5}$ Movementscape is a neologism coined by Lena Hammergren, describing transnational distribution of dance forms (Hammergren 2014). 
sions of the Finnish folk dance field. Their status is addressed, for example, in curricula of professional folk dancers' and folk dance teacher education, where different forms of Hungarian dances and Swedish polskas are usually the only foreign folk dance forms that are taught. However it must be noted that the Hungarian dances have increasingly become a curiosity, mostly among some male folk dancers, whereas Swedish polskas have been gaining popularity all the time, and they hold a more prominent position than the Hungarian dances in dance curricula as well.

\section{CONCLUSION}

One can say that absorbing Swedish and Hungarian elements into Finnish folk dance is a very common practice of transnational cultural adaptation in the age of globalization. Even if the interaction with both Swedish and Hungarian folk dancers has been created through bilateral contacts, they cannot be regarded as single cases, but they are a result of global trajectories that have been visible for several decades: festivals, organizations, folkloric elements as a part of international sports events. In this process, the dynamic and powerful forces of globalization and localization in transnational cultural flows can easily be seen. It would be tempting to regard the adaptation of foreign elements as simple copying, but a closer examination shows that these elements are creatively used as well as fused with Finnish folk dance. It is important to recognize the extent to which Swedish and Hungarian influences have stimulated artistic imagination and imaginary appropriation in Finland. Nowadays, one-way cultural flow is rare and different cultures usually compete and interact with each other (Wai-ming Ng 2005: 168-169).

The impact of Hungarian and Swedish elements on Finnish folk dance should be conceived of in the context of transnational cultural flows and cultural hybridization. Swedish polskas and various Hungarian dances have created a totally new level of folk dancing in Finland, representing a new technical quality and skills that are commonly pursued. The connection with Sweden and Hungary within these forms still exists, but it is seldom authoritative or compelling anymore. The indigenization of Swedish polskas and Hungarian dances means that they have been relocated and domesticated in Finland, and they have become a part of the embodied culture and discourse in the Finnish folk dance field. 


\section{REFERENCES AND SOURCES}

Alver, Brynjulf. 1980. "Nasjonalisme og identitet. Folklore og nasjonal utvikling”. In Folklore och nationsbyggande i Norden, Lauri Honko, ed. Turku: Nordiska institutet för folkdiktning. 5-16.

Appadurai, Arjun. 1996. Modernity at Large. Cultural Dimensions of Globalization. Minneapolis: University of Minnesota Press.

Collan, Anni. 1928. Suomalainen Kisapirtti. Helsinki: Kirja.

Danske Folkedanse, Beskrivelser I 1901. Udgivet af Foreningen til Folkdedansens Fremme.

Danske Folkedanse, Beskrivelser II 1903. Udgivet af Foreningen til Folkdedansens Fremme.

Danske Folkedanse, Beskrivelser III 1911. Udgivet af Foreningen til Folkdedansens Fremme.

Description of András Béres's lecture at Jyväskylän kesä. 1968. private archive (p. a.).

Description of the program of Saarenkylä Youth Club. 1992. Pispala Schottische archive (P. S. a.), Tampere.

30 folkdanser 1931. Utgivna av Föreningen Brage. Red. av Yngvar Heikel. Helsingfors.

Gotham, Kevin. 2005. "Tourism from Above and Below. Globalization, Localization and New Orleans's Mardi Gras". International Journal of Urban and Regional Research 29/2: 309326. [http://dx.doi.org/10.1111/j.1468-2427.2005.00586.x]

Hammergren, Lena. 2014. "Dancing African-American Jazz in the Nordic Region". In Nordic Dance Spaces. Practicing and Imagining a Region. Karen Vedel and Petri Hoppu, eds. Farnham: Ashgate, 101-127.

Heikkinen, Sirpa. 1989. “Opinhalua ja uteliaisuutta ei puutu”. Kaleva 12.3.1989.

Henry Sjöberg's description of the polskas from the international folk dance course in Orivesi. 1981. private archive (p. a.).

Hungarian folk dance instructions by Sirkka Viitanen and Ágoston Lányi. private archive (p. a.).

Hoppu, Petri. 2007. "Nya riktningar i det finska Finland". In Norden i dans. Folk - Fag - Forskning. Egil Bakka and Gunnel Biskop, eds. Oslo: Novus, 571-574.

Hoppu, Petri. 2011. "National Dances and Popular Education - The Formation of Folk Dance Canons in Norden". In Dance and the Formation of Norden. Emergences and Struggles. Karen Vedel, ed. Trondheim: Tapir, 27-56.

Hoppu, Petri. 2014. "Together and Apart. All-Nordic Folk Dance Events before 1975". In Nordic Dance Spaces. Practicing and Imagining a Region. Karen Vedel and Petri Hoppu, eds. Farnham: Ashgate, 207-232.

Huuskonen, Anna-Mari. 2001. Kansantanssi aatteena ja ajanvietteenä. Suomalaisen Kansantanssin Ystävät 1901-2001. Helsinki: SKY.

ISOT - Kansantanssia 50 vuotta. Available at: https://sites.google.com/site/isot50vuotta/historia-1/kansantanssi/2-4 (accessed 15 January 2014).

Katrilli - Historia. Available at: http://uusi.katrilli.fi/seura/historia/ (accessed 15 January 2014).

Kurkela, Vesa. 1986. Tanhuten valistukseen. Musiikkivalistus ja perinnetyö Suomen Demokraattisessa Nuorisoliitossa. Helsinki: Työväenmusiikki-instituutti.

Laitinen, Heikki. 1986. "Surullista, köyhää ja nöyrää. Musiikillisen kansakuvan syntyvaiheita ja seurauksia”. Musiikin suunta 8/3: 39-46.

Milad, Maria. 2002. PariTanssien - tanssitalokirja. Helsinki: Suomen Nuorisoseurojen Liitto. 
Nilsson, Mats. 2007. "Nytraditionalismen i Sverige". In Norden i dans. Folk - Fag - Forskning. Egil Bakka and Gunnel Biskop, eds. Oslo: Novus, 547-551.

Nilsson, Mats. 2009. Dans - polska på svenska. Gothenburg: Arkipelag.

Notes from the performance of Rimpparemmi. 1994. private archive (p. a.).

Nuorisoseurat - Tanssitalo-ohjaajakoulutus. Available at: http://www.nuorisoseurat.fi/tanssitalo-ohjaajakoulutus (accessed 15 January 2014).

Okstad, Kari M. 2007. "Ny inspirasjon i Norge”. In Norden i dans. Folk - Fag - Forskning. Egil Bakka and Gunnel Biskop, eds. Oslo: Novus, 561-570.

Peruskoulun kansantanssiohjelmistoa 1975. Kansantanssialan yhteistoimikunta.

Pulkkinen, Asko. 1929. Suomalaisia kansantanhuja. Helsinki: WSOY.

Rajalaakso, Marita. 1989. "Tanssitupatoiminnasta Virroilla". In Soivat Virrat. Musiikkikulttuurin tapausanalyyseja. Päivikki Suojanen, ed. Tampere: Tampereen yliopisto, 67-76.

Rausmaa, Pirkko-Liisa. 2007. Suomalaisen Kansantanssin Ystävät:s insamling och publicering. In Norden i dans. Folk - Fag - Forskning. Egil Bakka and Gunnel Biskop, eds. Oslo: Novus, 443-452.

Räsänen, Auli. 1998. "Kiitos unkarilaiset! Heimoveljet ovat vaikuttaneet suomalaisiin miestentansseihin". Helsingin Sanomat 30.3.1998.

Semb Klara. 1922. Norske Folkedansar, 2. Rettleiding um dansen. Oslo: Noregs Ungdomslag.

Shils, Edward. 1981. Tradition. Chicago: University of Chicago Press.

Svenska Folkdanser och Sällskapsdanser. 1933. Utgivna av Svenska Ungdomsringen för Bygdekultur. Redigerade av Gustaf Karlson. Stockholm.

Tanhurentut. Available at: http://www.tanhu.net/?page_id=223 (accessed 15 January 2014).

Unkari - Kahdenväliset suhteet. Available at: http://formin.finland.fi/public/default.aspx?nod eid=42895\&contentlan=1\&culture=fi-FI (accessed 9 May 2014).

Urup, Henning, Henry Sjöberg and Egil Bakka. 1988. Gammaldans i Norden. Trondheim: Nordisk forening for folkedansforskning.

Video of the folk dance choreography contest. 1994. Pispala Schottische archive (P. S. a.), Tampere.

Wai-ming Ng, Benjamin. 2005. "The Indigenization of Japanese Elements in Hong Kong TV Dramas". New Zealand Journal of Asian Studies 7/2: 153-170.

\title{
INDIGENIZACIJA ŠVEDSKIH I MAĐARSKIH ELEMENATA U FINSKOM FOLKLORNOM PLESU
}

\begin{abstract}
SAŽETAK
Ovaj se članak bavi utjecajem mađarskih folklornih plesova i švedskih plesova, polski, na finski folklorni ples. Na tragu ideja Kevina Gothama o kulturnoj razmjeni tvrdi se da razvoj nikako nije linearan, nego da ga se može promatrati kao složen i raznolik proces koji uključuje i homogenizacijske sile ujednačavanja kao i diverzifikacijske sile. Za istraživanje je ključan pojam indigenizacije Arjuna Appaduraia, kojim se
\end{abstract}


objašnjava na koji način globalne silnice utječu na lokalne prilike i kako se zatim te lokalne prilike mijenjaju da bi odrazile globalne utjecaje. Prihvaćanje švedskih i mađarskih elemenata u finski folklorni ples odraz je uobičajene prakse transnacionalne kulturne adaptacije, gdje se u transnacionalnim kulturnim tokovima jasno odražavaju dinamične i jake silnice globalizacije i lokalizacije. Švedske polske i mađarski plesovi doveli su do stvaranja sasvim nove razine folklornog plesanja u Finskoj, jer su donijeli nove tehnike i vještine kojima se danas u Finskoj teži. Kod tih plesnih oblika poveznica sa Švedskom i Mađarskom još uvijek postoji, ali je rijetko kad uočljiva. Švedske polske i mađarski plesovi preseljeni su u Finsku gdje su se udomaćili te su postali dijelom otjelovljene kulture i diskursa o finskome folklornom plesu.

Ključne riječi: indigenizacija, folklorni ples, izvedba, plesni događaj 